\title{
Reforming Spending Policy and its Impact on Indonesia's Economy: The Case of Fuel Subsidy and Infrastructure
}

\author{
Muhammad Anas \\ Universitas Muhammadiyah Surakarta \\ Corresponding Author: ma912@ums.ac.id
}

Recieved: February 2019 | Revised: February 2019 | Accepted: February 2019

\begin{abstract}
The quality of Indonesia's infrastructure up until 2014 was considered uncompetitive, and one of the reasons was that there was not enough money spent on infrastructure, and too much on fuel subsidy. In November 2014, the government of Indonesia decided to cut the expenditure for fuel subsidy and reallocate the money to invest on public services. This study was conducted with the intention to quantify the impact of the program on economic growth and income distribution in Indonesia using Social Accounting Matrix (SAM) model. Simulation results indicated that the impact from social and human capital infrastructure was bigger than that of economic infrastructure, although the simulation for both categories resulted in an increase of sectoral output and domestic income. Therefore, improving infrastructure, especially social, is vital to stimulate economic activity in the long run.
\end{abstract}

Keywords: fuel subsidy, infrastructure, SAM, sectoral output, household income JEL Classification: C12, C67, C68, H54, H72

How to Cite: Anas, M. (2019). Reforming Spending Policy and Its Impact on Indonesia's Economy: The Case of Fuel Subsidy and Infrastructure. Jurnal Ekonomi Pembangunan: Kajian Masalah Ekonomi dan Pembangunan, 20(1). doi:https://doi.org/10.23917/jep.v20i1.7733

DOI: https://doi.org/10.23917/jep.v20i1.7733

\section{Introduction}

Fiscal policy is one of the policies conducted by governments to stabilize a country's economy after the failure of laissez-faire economy. One way that governments can do to enhance the economy of a country is by investing on various sectors, and the details of all income and expenditure are recorded in State Budget. Based on the data from the Ministry of Finance (2014), Indonesia's spending increased dramatically by 71 percent from 2010 with 1042 trillion Rupiahs to 1777 trillion Rupiahs in 2014. As a result, budget deficit also worsened from only 47 trillion Rupiahs in 2010 to almost five times as high in 2014 (Table 1).

Table 1. Indonesia's Financial State 2010 - 2014

\begin{tabular}{cccc}
\hline \multirow{2}{*}{ Year } & Income & Spending & Deficit \\
\cline { 2 - 4 } & \multicolumn{3}{c}{ (Trillion Rupiahs) } \\
\hline 2010 & 995.27 & 1042.12 & 46.85 \\
2011 & 1210.60 & 1295.00 & 84.40 \\
2012 & 1338.11 & 1419.41 & 81.30 \\
2013 & 1438.89 & 1650.56 & 211.67 \\
2014 & 1550.49 & 1777.18 & 226.69 \\
\hline \multicolumn{3}{c}{ Source: Indonesia's Ministry of Finance }
\end{tabular}




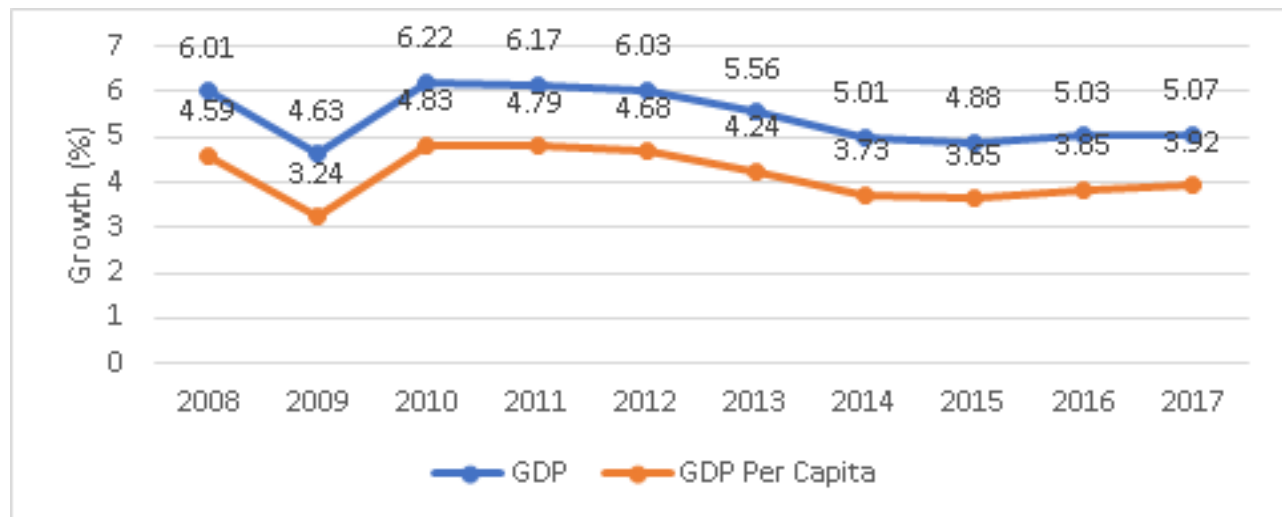

Figure 1: Indonesia's GDP and GDP Per Capita Growth

Source: World Bank

One of the reasons of the rapid surge of government spending was the consistently increasing expenditure on subsidy, particularly for fuel. In 2010, Indonesia's government spent 82 trillion Rupiahs for fuel subsidy, which then climed significantly to almost 240 trillion Rupiahs four years later. Unfortunately, most subsidized fuel consumers (86 percent) were those with upper-middle income (Diop, 2014). Not only that, fiscal room for productive sectors like infrastructure had narrowed.

Based on the report from The Global Competitivenes Report (GCR) 2015, quality infrastructure can cut transportation and transaction cost and enhance the movements of goods and services, and hence reduce indequality between regions. In order to reach a sustainable and competitive development, infrastructure is one of four most important pillars of a country, alongside institution, technological readiness, and macroeconomic condition. With adequate infrastructure, a country can attract investments relatively easier and thus fasten economic growth (Schwab, 2014).

According to the data from GCR, in 2014, it can be argued that Indonesia's infrastrcture was inadequate. Out of 144 countries, Indonesia's overall infrastructure sat on the $72^{\text {nd }}$ position, with the quality of roads and railroad being the worst with scores of 3.9 and 3.7, respectively (on the scale of 1 to 7). Also, inadequate supply of infrastructure was ranked $3^{\text {rd }}$ for the most problematic factors in doing business in Indonesia in 2015, below only corruption and inefficient government bureaucracy. This was indicated as a result of a very limited budget for infrastructure due to fuel subsidy spending.

It is feared that uncompetitive infrastructure was one of the causes of the decreasing economic growth in Indonesia. Based on Figure 1, it is noticeable that Indonesia's GDP and GDP per capita growth experienced a decreasing trend. In 2014 (the year of the spending policy reform hence becoming the focus of this study), GDP and GDP per capita growth was 5.01 and 3.73 percent, respectively, lower than the 2010 figures. It can be argued that little infrastructure spending (less 5 percent of Indonesia's GDP in 2013 and 2014 according to Diop (2014) played a role in this phenomena.

Considering how important infrastructure is for a country, Indonesia's government decided to reform their spending policy. In mid November 2014, they cut the budget for fuel subsidy from 239.99 trillion Rupiahs in 2014 to only 64.68 the year after. Fuel subsidy spending even experienced a falling trend since then (only 47.05 trillion in 2017 according to Indonesia's Ministry of Finance). The money was going to be allocated to invest on and improve infrastructure with the expectation of realizing sustainable development and enhancing Indonesia's competitiveness level.

This study aims to quantitatively estimate the impact of the budget reallocation from fuel subsidy to infrastructure on Indonesia's sectoral output growth and household income 
Jurnal Ekonomi Pembangunan: Kajian Masalah Ekonomi dan Pembangunan, 20 (1), 2019, 12-27

distribution. In general, there has been quite considerable amount of studies on this topic. However, this study offers a different approach by conducting two-stage policy simulation. Using Indonesia's Social Accounting Matrix (SAM), this study conducts a simulation by reducing fuel subsidy spending and reallocating it for infrastructure. Further analysis in this study is done by conducting a paired-sample test to find out if there is a difference in household income distribution after the simulation.

\section{Literature Review}

Studies on government's budgeting policy have been done various times, particularly about subsidy and infrastructure. One of the earlier studies was done by Aschauer (1989) who applied Ordinary Least Square (OLS) model and found that economic infrastructure (roads, airport, drainage, and electricity) played an important role in enhancing Total Factor Productivity (TFP) in the USA. Similar model was applied by Ford and Poret (1991) whose study indicated that the decreasing trend of American TFP was due to the fact that the infrastructure spending was limited. Chani, Jan, Pervaiz, and Chaudhary (2014) proved that there was causality between human capital and income OLS model was also used in recent studies, and one of them was by Palei (2015) where she found that improved infrastructure possitively affect Russia's competitiveness level. Although econometric models are able to accomodate long-run estimation, the analysis is not very comprehensive because there is only one dependent variable and that variable is not classified into specific categories. Therefore, this study will apply a general equilibrium model (SAM) for the quantitative estimation.

Raihan (2011) applied SAM model and found that the increase in infrastructure spending would stimulate Bangladesh's economic growth and increase household income. Another general equilibrium, which is input-output (IO) model, was also used by ("Transportation Infrastructure Investment: Macroeconomic and Industry Contribution of the Federal Highway and Mass
Transit Program," 2014) whose research proved that transportation infrastructure played an essential role in enhancing GDP and job opportunities in the USA. Meanwhile, Widodo, Sahadewo, Setiastuti, and Chaerriyah (2012) and Fathurrahman (2014) suggested that, using SAM simulation, the decrease in fuel subsidy spending would lower Indonesia's sectoral output and household income, but the economy could be revived by diverting the money to other sectors. That result was supported by Ogarenko and Hubacek (2013) and Cooke, Hague, Tiberti, Cockburn, and El Lahga (2016) with IO model. Meanwhile, evidence from Akinyemi, Alege, and Ajayi (2017) who applied CGE model stated that a complete removal of fuel subsidy would enhance economic growth and food security if the fund was diverted into infrastructure.

This study attempts to conduct a further analysis compared to the previous ones. Here, a hyphotesis test will be done using $t$ test to find out if the policy simulation will make a difference in the distribution of household income.

\section{Research Methods \\ 3.1 Multiplier Effect}

Although the latest Indonesia's SAM was from 2008, it is still relevant until present days. That is due to the fact that the SAM multiplier is based on the Average Expenditure Propensity (AEP), and it is found that there is not much difference from 1975 and 2008 SAM AEP (see Appendix 2). It indicates that Indonesia's economy has not changed much, especially in terms of technological progress. In order to estimate the impact of a shock in the exogenous variables on the endogenous ones, this study will calculate the SAM multiplier effect using the following formula:

$\mathrm{y}=\operatorname{Max}$

Based on Equation (1), $y$ is the endonegnous variable, $M_{a}$ is the multiplier in the economy, and $x$ is the exogenous variable. In this study, $y$ is represented by sectoral output and household income, while $x$ is the policy simulation where 
Jurnal Ekonomi Pembangunan: Kajian Masalah Ekonomi dan Pembangunan, 20 (1), 2019, 12-27

fuel subsidy spending will be reduced and infrastructure spending will be increased. The multiplier effect tells us how much $y$ will change if there is a one unit change in $x$.

\subsection{Policy Simulation Scenarios}

There are two policies that will be simulated in this study. The first policy is cutting expenditure for fuel subsidy, and the second policy is reallocating the money for infrastructure spending. According to microeconomic theory, the increase in price will decrease the quantity of goods demanded. Based on the data taken from Indonesia's Ministry of Energy and Mineral Resources, the consumption of oil fuel by transportation sector in 2014 was 42.26 million kilo liters, and the figure fell to 41.25 one year after (after the fuel price was increased from 6500 Rupiahs to 8500).

After calculating, it is found that the spending (in money) for oil fuel by transportation sector fell by 21.65 percent. Meanwhile, electricity sector also experienced a fall in oil fuel spending by 23.08 percent. This research chose transportation and electricity sectors for the fuel subsidy policy simulation based on the fact that the oil fuel that they use for production is subsidized by Indonesia's government. The shock for the cut in fuel subsidy spending will be calculated by multiplying the fall (in percentage) in oil fuel spending with the difference in fuel subsidy spending in Indonesia between 2014 and 2015, which was 169.03 trillion Rupiahs.

Moving on to the infrastructure policy, the World Bank classifies economic infrastructure into transportation infrastructure, electricity installation, irrigation, drainage, and telecommunication networks. Based on Indonesia's SAM, they are best classified into sector 41 (Construction). Meanwhile, social infrastructure includes education, health, and recreation, and they are best classified into sector 49 (Government and defence, education, health, other social services, film, and recreation) (Indonesia's SAM table can be seen in Appendix $1)$.
The underlying assumption in this research is that all money from the fuel subsidy budget cut is reallocated for infrastructure. The simulation is then divided into four different scenarios. The first and second scenarios will be allocating all money for sector 41 (construction) and 49 (education and health). Third scenario is to allocate the money for both sectors equally, and the last scenario is that 78 percent of the money is allocated for sector 41 and 22 percent for sector 49 . This share is based on the articles from Indonesia's Cabinet Secretariat (2015) and KataData (2015).

\subsection{Paired-sample Test}

Hypothesis test in this study is based on paired-sample $t$ test, because the sample is taken from the income of household categories that are listed on Indonesia's SAM, before and after the policy simulation is conducted. The hypotheses are formulated as follows:

$\mathrm{H}_{0}$ : Household income after the policy simulation is conducted is equal to or lower than the figure before the policy simulation is conducted

$\mathrm{H}_{\mathrm{a}}$ : Household income after the policy simulation is conducted is higher than the figure before the policy simulation is conducted

Meanwhile, hypotheses for the proportion of household income are formulated as follows:

$\mathrm{H}_{0}$ : There is no difference in houseold income distribution between before and after the policy simulation is conducted

$\mathrm{H}_{\mathrm{a}}$ : There is a difference in houseold income distribution between before and after the policy simulation is conducted

The conclusion of the test will rely on the significance level of the $t_{\text {statistic }}$. If the value exceeds a, $\mathrm{H}_{0}$ is rejected (Santoso, 2018). In this study, the a used is 5 percent.

\section{Results and Discussions}

The results of this study pretty much support the results from previous studies, since it is a simulation analysis. After the simulation of 
reducing fuel subsidy was conducted, Indonesia's economy worsened, which was indicated by the decrease in sectoral output and household income. However, after the shock in infrastructure, the economy grew again.

\subsection{Changes in Sectoral Output}

At first, Indonesia's sectoral output decreased by 1.21 percent in total due to the fuel subsidy budget cut, with electricity experiencing the biggest downfall with 8.40 percent. This is due to the fact that as transportation and electricity sectors reduce their spending for oil fuel, their output decreased because oild fuel is their raw material for production and that affected the production and income of other sectors. However, the shock in infrastructure from all four scenarios resulted in the increase of sectoral output by $6.27,6.65,6.46$, and 6.36 percent, respectively. (See Appendix 3-6 for the detailed results), which means that sectoral output grew by over 5 percent. Transportation and education and health experienced the highest rise of output.

This study indicates that scenario 2 , which is the reallocation of the budget fully for sector 49 (education and health) resulted in the highest increase in sectoral output (in percentage). Education and health are components of human capital that are embedded in labor force and are important to improve the quality of labor and society in general, and therefore able to accelerate economic growth.

\subsection{Changes in Household Income}

Following the shock from the decrease in fuel subsidy expenditure, Indonesia's household income fell by 1.24 percent in general. With higher fuel price, people have to spend more to buy goods and services. The highest fall of income was experienced by upper-class urban households (code 25), which was 1.34 percent.

However, the infrastructure shock from all scenarios generated an increase in household income that was higher than the fall caused by the subsidy shock $(5.89,8.44,7.17$, and 6.45 percent, respectively for each scenario). Just like in output changes, scenario 2 resulted the highest household income increase, with upper-class rural (code 22) and upper-class urban hosueholds (code 25) benefiting from the policy (see Appendix 7 and 8). Improving infrastructure can enhance connectivity between regions so that inequality and poverty can be alleviated more quickly.

From the hypothesis test, the first $t$ test resulted in significance levels of less than 5 percent in all four scenarios (see Appendix 9), which means that $\mathrm{H}_{0}$ is rejected. Therefore, it can be concluded that household income after the simulation is higher than before. Meanwhile, the significance levels from the second $t$ test indicate that there is no difference in income distribution between before and after the simulation was conducted. Farm workers (code 18) and rural households (code 20) still only taste a small share of income.

\section{Conclusion}

Subsidized fuel in Indonesia has always been consumed by upper-class citizens more than lower-class ones. Not only that, the budget to invest on infrastructure was narrow due to the increasing spending for fuel subsidy. Based on that fact, at the end of 2014, the government of Indonesia cut the fuel subsidy spending and diverting it to improve infrastructure.

This study found that the increase in sectoral output and household income from the infrastructure shock was higher than the decrease caused by the subsidy shock. Moreover, human capital infrastructure played a bigger role in rising output and income, although it did not change the proportion of income among household categories. It is imperative that Indonesian government put infrastructure as one of their priorities in the future as it is capable of enhancing economic activity.

\section{Limitation Of The Study}

This research only focused on the policy conducted in November 2014, which was reducing fuel subsidy spending. Therefore, the data taken was only from before the policy (2014) and right 
Jurnal Ekonomi Pembangunan: Kajian Masalah Ekonomi dan Pembangunan, 20 (1), 2019, 12-27

after the policy (2015). Not only that, there is no specific detail as to where the money from the budget cut is allocated, so it was extremely assumed that all money went to infrastructure. For future studies, it is suggested that authors seek for further information from reliable sources.

\section{References}

Akinyemi, O., Alege, P. O., \& Ajayi, O. (2017). A Simulation of the Removal of Fuel Subsidy and the Performance of the Agricultural Sector in Nigeria using a Dynamic Computable General Equilibrium Approach. Covenant Journal of Business \& Social Sciences (CJBSS), 8(1), 60-70.

Aschauer, D. (1989). Is Public Expenditure Productive? Journal of Monetary Economics, 23(September 1988), 177-200. https://doi. org/10.1103/PhysRevLett.92.157006

Cabinet Secretariat. (2015). Berterima Kasih Kepada Rakyat, Presiden Jokowi Jelaskan Alokasi Pengalihan Anggaran Subsidi BBM. Retrieved from https://setkab.go.id/ berterima-kasih-kepada-rakyat-presidenjokowi-jelaskan-alokasi-pengalihananggaran-subsidi-bbm/

Chani, M. I., Jan, S. A., Pervaiz, Z., \& Chaudhary, A. R. (2014). Human Capital Inequality and Income Inequality: Testing for Causality. Quality and Quantity, 48(1), 149-156. https://doi.org/10.1007/s11135-012-9755-7

Cooke, E. F. A., Hague, S., Tiberti, L., Cockburn, J., \& El Lahga, A.-R. (2016). Estimating the impact on poverty of Ghana's fuel subsidy reform and a mitigating response. Journal of Development Effectiveness, 8(1), 105-128.

Diop, N. (2014). Why Is Reducing Energy Subsidies a Prudent, Fair, and Transformative Policy for Indonesia? World Bank-Economic Premise.

Fathurrahman, F. (2014). Simulating Indonesian Fuel Subsidy Reform: A Social Accounting
Matrix (SAM) Analysis. The Graduate School of Natural and Applied Sciences of Middle East Technical University. Middle East Technical University.

Ford, R., \& Poret, P. (1991). Infrastructure and Private Sector Productivity. Economic Studies, (17).

Indonesia's Ministry of Finance. (2018). Laporan Keuangan Pemerintah Pusat. Jakarta. Retrieved from https://www.kemenkeu. go.id/publikasi/laporan/laporan-keuanganpemerintah-pusat/

KataData. (2015). Kemana Pengalihan Dana Subsidi BBM.

Palei, T. (2015). Assessing the Impact of Infrastructure on Economic Growth and Global Competitiveness. Procedia Economics and Finance, 23(October 2014), 168-175. https://doi.org/10.1016/S22125671(15)00322-6

Raihan, S. (2011). Infrastructure and Growth and Poverty in Bangladesh. Munich Personal RePEc Archive, (37882).

Santoso, S. (2018). Menguasai Statistik dengan SPSS 25. Jakarta: PT Elex Media Komputindo.

Schwab, K., \& World Economic Forum. (2014). The Global Competitiveness Report 20142015. World Economic Forum Reports 2014. https://doi.org/ISBN-13: 978-92-95044-73-9

Transportation Infrastructure Investment: Macroeconomic and Industry Contribution of the Federal Highway and Mass Transit Program. (2014), (December).

Widodo, T., Sahadewo, G. A., Setiastuti, S. U., \& Chaerriyah, M. (2012). Impact of Fuel Subsidy Removal on Government Spending. Energy Market Integration in East Asia: Theories, Electricity Sector and Subsidies, (August), 173-206. 


\section{Appendix}

Appendix 1. Endogenous Account from Indonesia's SAM

\begin{tabular}{|c|c|c|c|}
\hline & Blocks & Details & \\
\hline \multirow{8}{*}{ 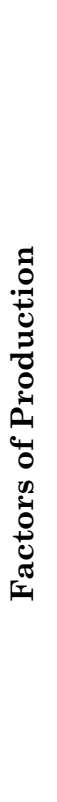 } & \multirow{8}{*}{$\frac{\ddot{8}}{\stackrel{\sigma}{\sigma}}$} & Farm (paid) & $\begin{array}{l}1 \\
2\end{array}$ \\
\hline & & Farm (unpaid) & $\begin{array}{l}3 \\
4\end{array}$ \\
\hline & & $\begin{array}{l}\text { Production, transportation } \\
\text { operator, and unskilled (paid) }\end{array}$ & $\begin{array}{l}5 \\
6\end{array}$ \\
\hline & & $\begin{array}{l}\text { Production, transportation equipment } \\
\text { operator, and unskilled (unpaid) }\end{array}$ & $\begin{array}{l}7 \\
8\end{array}$ \\
\hline & & Administration, sales, services (paid) & $\begin{array}{c}9 \\
10\end{array}$ \\
\hline & & Administration, sales, services (unpaid) & 11 \\
\hline & & $\begin{array}{l}\text { Management, military, professional, } \\
\text { technician (paid) }\end{array}$ & $\begin{array}{l}13 \\
14\end{array}$ \\
\hline & & $\begin{array}{l}\text { Management, military, professional, } \\
\text { technician (unpaid) }\end{array}$ & $\begin{array}{l}15 \\
16\end{array}$ \\
\hline \multirow{11}{*}{ 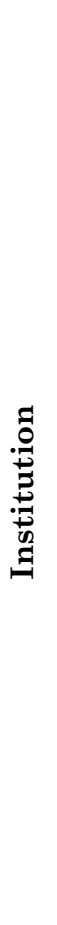 } & \multirow{9}{*}{ 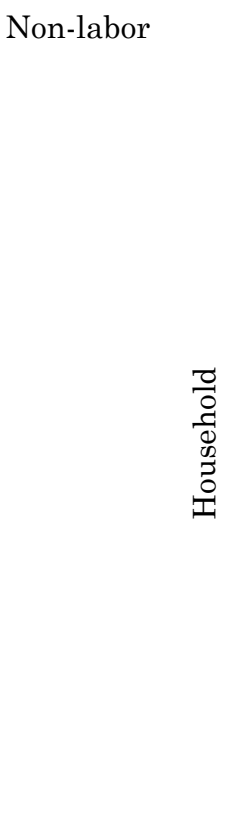 } & & 17 \\
\hline & & Farm workers & 18 \\
\hline & & Agricultural entrepreneur & 19 \\
\hline & & $\begin{array}{l}\text { Lower-class entrepreneur, administration, } \\
\text { traveling salesman, freelancer, individual } \\
\text { services, unskilled labor }\end{array}$ & 20 \\
\hline & & Non labor force and unclear category & 21 \\
\hline & & $\begin{array}{l}\text { Upper-class entrepreneur, non-agricultural } \\
\text { entrepreneur, manager, military, professional, } \\
\text { upper-class technician, teacher, and } \\
\text { administration }\end{array}$ & 22 \\
\hline & & $\begin{array}{l}\text { Lower-class entrepreneur, administration, } \\
\text { traveling salesman, freelancer, individual } \\
\text { services, unskilled labor }\end{array}$ & 23 \\
\hline & & Non labor force and unclear category & 24 \\
\hline & & $\begin{array}{l}\text { Upper-class entrepreneur, non-agricultural } \\
\text { entrepreneur, manager, military, professional, } \\
\text { upper-class technician, teacher, and } \\
\text { administration }\end{array}$ & 25 \\
\hline & \multicolumn{2}{|l|}{ Firm } & 26 \\
\hline & \multicolumn{2}{|l|}{ Government } & 27 \\
\hline
\end{tabular}


Avalaible online at http://journals.ums.ac.id, Permalink/DOI: 10.23917/jep.v20i1.7733

Jurnal Ekonomi Pembangunan: Kajian Masalah Ekonomi dan Pembangunan, 20 (1), 2019, 12-27

\begin{tabular}{|c|c|c|c|}
\hline & Blocks & Details & \\
\hline \multirow{22}{*}{ 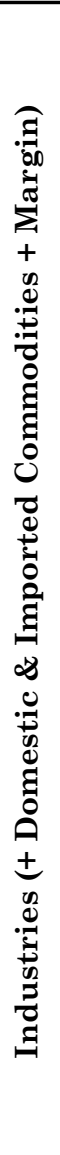 } & \multirow{5}{*}{ Agriculture } & Crops & 28 \\
\hline & & Other plants & 29 \\
\hline & & Livestock & 30 \\
\hline & & Forestry & 31 \\
\hline & & Fishery & 32 \\
\hline & \multirow{3}{*}{ Mining } & Coal, metal ore, and crude oil & 33 \\
\hline & & Other mining \& excavation & 34 \\
\hline & & Food, beverage, and tobacco & 35 \\
\hline & \multirow{6}{*}{ Manufacturing } & Spinning, textile, clothing, and leather & 36 \\
\hline & & Wood & 37 \\
\hline & & Paper \& printing, transportation equipment & 38 \\
\hline & & Chemical, fertilizer, clay, cement & 39 \\
\hline & & Electricity, Gas and drinking water & 40 \\
\hline & & Construction & 41 \\
\hline & \multirow{4}{*}{$\begin{array}{l}\text { Wholesale, Restaurant \& } \\
\text { Hotels, Transportation \& } \\
\text { Communication }\end{array}$} & Wholesail \& retail & 42 \\
\hline & & Restaurant & 43 \\
\hline & & Hotels & 44 \\
\hline & & Transportation & 45 \\
\hline & Financial Institutions, Real & Banking and insurance & 47 \\
\hline & Estate, Governmental, & Real estate and company services & 48 \\
\hline & \multirow{2}{*}{$\begin{array}{l}\text { Cultures, Entertainment, } \\
\text { Individual Services }\end{array}$} & $\begin{array}{l}\text { Government and defence, education, health, films, } \\
\text { and recreation }\end{array}$ & 49 \\
\hline & & Individual and other services & 50 \\
\hline
\end{tabular}

Source: Statistics Indonesia

Note: This is a modified SAM from a 102x102 sector Indonesia's SAM 
Avalaible online at http://journals.ums.ac.id, Permalink/DOI: 10.23917/jep.v20i1.7733

Jurnal Ekonomi Pembangunan: Kajian Masalah Ekonomi dan Pembangunan, 20 (1), 2019, 12-27

Appendix 2. Average Expenditure Propensity (AEP) from Indonesia's SAM 1975 and 2008

AEP from Indonesia's SAM 1975

\begin{tabular}{cccccccccc}
\hline Code & $\mathbf{1}$ & $\mathbf{2}$ & $\mathbf{3}$ & $\mathbf{4}$ & $\mathbf{5}$ & $\mathbf{6}$ & $\mathbf{7}$ & $\mathbf{8}$ & $\mathbf{9}$ \\
\hline 1 & $0.00 \%$ & $0.00 \%$ & $0.00 \%$ & $0.00 \%$ & $0.00 \%$ & $24.72 \%$ & $0.00 \%$ & $0.00 \%$ & $0.00 \%$ \\
2 & $0.00 \%$ & $0.00 \%$ & $0.00 \%$ & $0.00 \%$ & $0.00 \%$ & $38.29 \%$ & $0.00 \%$ & $0.00 \%$ & $0.00 \%$ \\
3 & $100.00 \%$ & $43.43 \%$ & $2.16 \%$ & $16.35 \%$ & $9.16 \%$ & $0.00 \%$ & $0.00 \%$ & $0.00 \%$ & $0.00 \%$ \\
4 & $0.00 \%$ & $47.06 \%$ & $0.00 \%$ & $0.78 \%$ & $0.00 \%$ & $0.00 \%$ & $0.00 \%$ & $0.00 \%$ & $0.00 \%$ \\
5 & $0.00 \%$ & $0.73 \%$ & $1.20 \%$ & $37.53 \%$ & $0.00 \%$ & $0.00 \%$ & $0.00 \%$ & $0.00 \%$ & $0.00 \%$ \\
6 & $0.00 \%$ & $0.00 \%$ & $0.00 \%$ & $0.00 \%$ & $0.00 \%$ & $0.00 \%$ & $0.00 \%$ & $90.35 \%$ & $0.00 \%$ \\
7 & $0.00 \%$ & $0.00 \%$ & $0.00 \%$ & $0.00 \%$ & $0.00 \%$ & $0.00 \%$ & $0.00 \%$ & $8.47 \%$ & $18.52 \%$ \\
8 & $0.00 \%$ & $0.00 \%$ & $83.98 \%$ & $0.00 \%$ & $53.40 \%$ & $28.35 \%$ & $100.00 \%$ & $0.00 \%$ & $0.00 \%$ \\
9 & $0.00 \%$ & $0.00 \%$ & $5.70 \%$ & $0.00 \%$ & $6.13 \%$ & $8.63 \%$ & $0.00 \%$ & $0.00 \%$ & $0.00 \%$ \\
\hline & & & AEP from Indonesia's SAM $\mathbf{2 0 0 8}$ & & $\mathbf{5} \%$ & $\mathbf{8}$ & $\mathbf{9}$ \\
\hline Code & $\mathbf{1}$ & $\mathbf{2}$ & $\mathbf{3}$ & $\mathbf{4}$ & $\mathbf{5}$ & $\mathbf{6}$ & $\mathbf{7}$ & $0.00 \%$ \\
1 & $0.00 \%$ & $0.00 \%$ & $0.00 \%$ & $0.00 \%$ & $0.00 \%$ & $25.95 \%$ & $0.00 \%$ & $0.00 \%$ & $0.00 \%$ \\
2 & $0.00 \%$ & $0.00 \%$ & $0.00 \%$ & $0.00 \%$ & $0.00 \%$ & $23.75 \%$ & $0.00 \%$ & $0.00 \%$ & $0.00 \%$ \\
3 & $99.80 \%$ & $31.91 \%$ & $1.13 \%$ & $2.25 \%$ & $15.75 \%$ & $0.00 \%$ & $0.00 \%$ & $0.00 \%$ & $0.00 \%$ \\
4 & $0.00 \%$ & $64.40 \%$ & $0.92 \%$ & $9.21 \%$ & $7.10 \%$ & $0.00 \%$ & $0.00 \%$ & $0.00 \%$ & $0.00 \%$ \\
5 & $0.00 \%$ & $0.00 \%$ & $2.22 \%$ & $33.92 \%$ & $14.37 \%$ & $0.00 \%$ & $0.00 \%$ & $0.00 \%$ & $0.00 \%$ \\
6 & $0.00 \%$ & $0.00 \%$ & $0.00 \%$ & $0.00 \%$ & $0.00 \%$ & $0.00 \%$ & $0.00 \%$ & $89.16 \%$ & $0.00 \%$ \\
7 & $0.00 \%$ & $0.00 \%$ & $0.00 \%$ & $0.00 \%$ & $0.00 \%$ & $0.00 \%$ & $0.00 \%$ & $8.77 \%$ & $10.49 \%$ \\
8 & $0.00 \%$ & $0.00 \%$ & $77.71 \%$ & $0.00 \%$ & $21.92 \%$ & $40.39 \%$ & $100.00 \%$ & $0.00 \%$ & $0.00 \%$ \\
9 & $0.00 \%$ & $0.00 \%$ & $9.01 \%$ & $0.00 \%$ & $1.38 \%$ & $9.91 \%$ & $0.00 \%$ & $0.00 \%$ & $0.00 \%$ \\
\hline
\end{tabular}


Avalaible online at http://journals.ums.ac.id, Permalink/DOI: 10.23917/jep.v20i1.7733

Jurnal Ekonomi Pembangunan: Kajian Masalah Ekonomi dan Pembangunan, 20 (1), 2019, 12-27

Appendix 3. Changes in Sectoral Output from Scenario 1

\begin{tabular}{|c|c|c|c|c|}
\hline \multirow{2}{*}{ Code } & Initial Output & New Output & Changes & \multirow{2}{*}{$\frac{\text { Growth }}{(\%)}$} \\
\hline & & (Trillion Rupiahs) & & \\
\hline 28 & 1091.58 & 1138.54 & 46.96 & $4.30 \%$ \\
\hline 29 & 438.37 & 454.15 & 15.78 & $3.60 \%$ \\
\hline 30 & 624.30 & 652.77 & 28.46 & $4.56 \%$ \\
\hline 31 & 116.82 & 128.21 & 11.40 & $9.76 \%$ \\
\hline 32 & 428.95 & 448.22 & 19.26 & $4.49 \%$ \\
\hline 33 & 1384.44 & 1411.87 & 27.43 & $1.98 \%$ \\
\hline 34 & 190.53 & 217.05 & 26.52 & $13.92 \%$ \\
\hline 35 & 2245.56 & 2332.18 & 86.62 & $3.86 \%$ \\
\hline 36 & 654.70 & 670.51 & 15.81 & $2.42 \%$ \\
\hline 37 & 390.80 & 419.74 & 28.94 & $7.41 \%$ \\
\hline 38 & 3395.65 & 3554.85 & 159.20 & $4.69 \%$ \\
\hline 39 & 2864.69 & 2984.14 & 119.45 & $4.17 \%$ \\
\hline 40 & 330.54 & 313.06 & -17.48 & $-5.29 \%$ \\
\hline 41 & 2463.96 & 2854.74 & 390.77 & $15.86 \%$ \\
\hline 42 & 3074.87 & 3207.20 & 132.33 & $4.30 \%$ \\
\hline 43 & 588.12 & 615.13 & 27.01 & $4.59 \%$ \\
\hline 44 & 98.41 & 100.96 & 2.54 & $2.59 \%$ \\
\hline 45 & 1440.64 & 1444.05 & 3.41 & $0.24 \%$ \\
\hline 47 & 548.73 & 574.12 & 25.39 & $4.63 \%$ \\
\hline 48 & 633.27 & 666.24 & 32.96 & $5.20 \%$ \\
\hline 49 & 1004.34 & 1042.69 & 38.35 & $3.82 \%$ \\
\hline 50 & 297.09 & 308.15 & 11.06 & $3.72 \%$ \\
\hline Total & 24306.36 & 25538.56 & 1.232 .21 & $5.06 \%$ \\
\hline
\end{tabular}

Source: Indonesia's SAM after simulation

Note: This is a result from the decrease in output caused by subsidy plus $(1.21 \%$ decrease in output) the increase in output caused by infrastructure shock ( $6.27 \%$ increase in output) 
Avalaible online at http://journals.ums.ac.id, Permalink/DOI: 10.23917/jep.v20i1.7733

Jurnal Ekonomi Pembangunan: Kajian Masalah Ekonomi dan Pembangunan, 20 (1), 2019, 12-27

Appendix 4. Changes in Sectoral Output from Scenario 2

\begin{tabular}{|c|c|c|c|c|}
\hline \multirow{2}{*}{ Code } & Initial Output & New Output & Changes & Growth \\
\hline & \multicolumn{3}{|c|}{ (Trillion Rupiahs) } & $(\%)$ \\
\hline 28 & 1091.58 & 1185.79 & 94.21 & $8.63 \%$ \\
\hline 29 & 438.37 & 461.20 & 22.83 & $5.21 \%$ \\
\hline 30 & 624.30 & 675.90 & 51.60 & $8.26 \%$ \\
\hline 31 & 116.82 & 119.17 & 2.35 & $2.01 \%$ \\
\hline 32 & 428.95 & 460.88 & 31.93 & $7.44 \%$ \\
\hline 33 & 1384.44 & 1405.57 & 21.13 & $1.53 \%$ \\
\hline 34 & 190.53 & 193.12 & 2.59 & $1.36 \%$ \\
\hline 35 & 2245.56 & 2395.21 & 149.65 & $6.66 \%$ \\
\hline 36 & 654.70 & 677.70 & 23.01 & $3.51 \%$ \\
\hline 37 & 390.80 & 398.89 & 8.10 & $2.07 \%$ \\
\hline 38 & 3395.65 & 3498.48 & 102.84 & $3.03 \%$ \\
\hline 39 & 2864.69 & 2960.76 & 96.07 & $3.35 \%$ \\
\hline 40 & 330.54 & 315.89 & -14.64 & $-4.43 \%$ \\
\hline 41 & 2463.96 & 2474.45 & 10.48 & $0.43 \%$ \\
\hline 42 & 3074.87 & 3224.81 & 149.95 & $4.88 \%$ \\
\hline 43 & 588.12 & 625.46 & 37.34 & $6.35 \%$ \\
\hline 44 & 98.41 & 101.96 & 3.55 & $3.61 \%$ \\
\hline 45 & 1440.64 & 1454.71 & 14.07 & $0.98 \%$ \\
\hline 47 & 548.73 & 577.33 & 28.61 & $5.21 \%$ \\
\hline 48 & 633.27 & 667.17 & 33.89 & $5.35 \%$ \\
\hline 49 & 1004.34 & 1442.68 & 438.34 & $43.65 \%$ \\
\hline 50 & 297.09 & 311.79 & 14.70 & $4.95 \%$ \\
\hline Total & 24306.36 & 25628.95 & 1322.59 & $5.44 \%$ \\
\hline
\end{tabular}

Source: Indonesia's SAM after simulation

Note: This is a result from the decrease in output caused by subsidy shock (1.21\% decrease in output) plus the increase in output caused by infrastructure shock (6.65\% increase in output) 
Avalaible online at http://journals.ums.ac.id, Permalink/DOI: 10.23917/jep.v20i1.7733

Jurnal Ekonomi Pembangunan: Kajian Masalah Ekonomi dan Pembangunan, 20 (1), 2019, 12-27

Appendix 5. Changes in Sectoral Output from Scenario 3

\begin{tabular}{|c|c|c|c|c|}
\hline \multirow{2}{*}{ Code } & Initial Output & New Output & Changes & \multirow{2}{*}{$\begin{array}{c}\text { Growth } \\
(\%)\end{array}$} \\
\hline & & (Trillion Rupiahs) & & \\
\hline 28 & 1091.58 & 1162.17 & 70.58 & $6.47 \%$ \\
\hline 29 & 438.37 & 457.68 & 19.31 & $4.40 \%$ \\
\hline 30 & 624.30 & 664.33 & 40.03 & $6.41 \%$ \\
\hline 31 & 116.82 & 123.69 & 6.87 & $5.88 \%$ \\
\hline 32 & 428.95 & 454.55 & 25.60 & $5.97 \%$ \\
\hline 33 & 1384.44 & 1408.72 & 24.28 & $1.75 \%$ \\
\hline 34 & 190.53 & 205.09 & 14.56 & $7.64 \%$ \\
\hline 35 & 2245.56 & 2363.70 & 118.13 & $5.26 \%$ \\
\hline 36 & 654.70 & 674.11 & 19.41 & $2.96 \%$ \\
\hline 37 & 390.80 & 409.32 & 18.52 & $4.74 \%$ \\
\hline 38 & 3395.65 & 3526.67 & 131.02 & $3.86 \%$ \\
\hline 39 & 2864.69 & 2972.45 & 107.76 & $3.76 \%$ \\
\hline 40 & 330.54 & 314.48 & -16.06 & $-4.86 \%$ \\
\hline 41 & 2463.96 & 2664.59 & 200.63 & $8.14 \%$ \\
\hline 42 & 3074.87 & 3216.01 & 141.14 & $4.59 \%$ \\
\hline 43 & 588.12 & 620.29 & 32.18 & $5.47 \%$ \\
\hline 44 & 98.41 & 101.46 & 3.05 & $3.10 \%$ \\
\hline 45 & 1440.64 & 1449.38 & 8.74 & $0.61 \%$ \\
\hline 47 & 548.73 & 575.72 & 27.00 & $4.92 \%$ \\
\hline 48 & 633.27 & 666.70 & 33.43 & $5.28 \%$ \\
\hline 49 & 1004.34 & 1242.68 & 238.35 & $23.73 \%$ \\
\hline 50 & 297.09 & 309.97 & 12.88 & $4.34 \%$ \\
\hline Total & 24306.36 & 25583.75 & 1277.40 & $5.25 \%$ \\
\hline
\end{tabular}

Source: Indonesia's SAM after simulation

Note: This is a result from the decrease in output caused by subsidy shock (1.21\% decrease in output) plus the increase in output caused by infrastructure shock (6.46\% increase in output) 
Avalaible online at http://journals.ums.ac.id, Permalink/DOI: 10.23917/jep.v20i1.7733

Jurnal Ekonomi Pembangunan: Kajian Masalah Ekonomi dan Pembangunan, 20 (1), 2019, 12-27

Appendix 6. Changes in Sectoral Output from Scenario 4

\begin{tabular}{|c|c|c|c|c|}
\hline \multirow{2}{*}{ Code } & Initial Output & New Output & Changes & Growth \\
\hline & \multicolumn{2}{|r|}{ (Trillion Rupiahs) } & \multicolumn{2}{|r|}{$(\%)$} \\
\hline 28 & 1091.58 & 1148.94 & 57.35 & $5.25 \%$ \\
\hline 29 & 438.37 & 455.70 & 17.33 & $3.95 \%$ \\
\hline 30 & 624.30 & 657.85 & 33.55 & $5.37 \%$ \\
\hline 31 & 116.82 & 126.22 & 9.41 & $8.05 \%$ \\
\hline 32 & 428.95 & 451.00 & 22.05 & $5.14 \%$ \\
\hline 33 & 1384.44 & 1410.49 & 26.05 & $1.88 \%$ \\
\hline 34 & 190.53 & 211.79 & 21.26 & $11.16 \%$ \\
\hline 35 & 2245.56 & 2346.05 & 100.49 & $4.47 \%$ \\
\hline 36 & 654.70 & 672.09 & 17.40 & $2.66 \%$ \\
\hline 37 & 390.80 & 415.15 & 24.35 & $6.23 \%$ \\
\hline 38 & 3395.65 & 3542.45 & 146.80 & $4.32 \%$ \\
\hline 39 & 2864.69 & 2979.00 & 114.31 & $399 \%$ \\
\hline 40 & 330.54 & 313.68 & -16.86 & $-5.10 \%$ \\
\hline 41 & 2463.96 & 2771.07 & 307.11 & $12.46 \%$ \\
\hline 42 & 3074.87 & 3211.07 & 136.21 & $4.43 \%$ \\
\hline 43 & 588.12 & 617.40 & 29.28 & $4.98 \%$ \\
\hline 44 & 98.41 & 101.18 & 2.77 & $2.81 \%$ \\
\hline 45 & 1440.64 & 1446.40 & 5.76 & $0.40 \%$ \\
\hline 47 & 548.73 & 574.82 & 26.10 & $4.76 \%$ \\
\hline 48 & 633.27 & 666.44 & 33.17 & $5.24 \%$ \\
\hline 49 & 1004.34 & 1130.69 & 126.35 & $12.58 \%$ \\
\hline 50 & 297.09 & 308.95 & 11.86 & $3.99 \%$ \\
\hline Total & 24306.36 & 25558.45 & 1252.09 & $5.15 \%$ \\
\hline
\end{tabular}

Source: Indonesia's SAM after simulation

Note: This is a result from the decrease in output caused by subsidy shock (1.21\% decrease in output) plus the increase in output caused by infrastructure shock ( $6.36 \%$ increase in output) 
Avalaible online at http://journals.ums.ac.id, Permalink/DOI: 10.23917/jep.v20i1.7733

Jurnal Ekonomi Pembangunan: Kajian Masalah Ekonomi dan Pembangunan, 20 (1), 2019, 12-27

Appendix 7. Changes in Household Income from Scenarios 1 dan 2 Scenario 1:

\begin{tabular}{ccccc}
\hline \multirow{2}{*}{ code } & Initial Income & New Income & Changes & Growth \\
\cline { 2 - 5 } & & (Trillion Rupiahs) & & $\mathbf{( \% )}$ \\
\hline 18 & 176.76 & 184.31 & 7.55 & $4.27 \%$ \\
19 & 731.56 & 764.11 & 32.54 & $4.45 \%$ \\
20 & 494.23 & 520.39 & 26.16 & $5.29 \%$ \\
21 & 173.15 & 181.41 & 8.26 & $4.77 \%$ \\
22 & 468.45 & 489.83 & 21.38 & $4.56 \%$ \\
23 & 710.50 & 745.08 & 34.59 & $4.87 \%$ \\
24 & 243.91 & 255.27 & 11.37 & $4.66 \%$ \\
25 & 827.88 & 864.33 & 36.44 & $4.40 \%$ \\
\hline Total & 3826.44 & 4004.73 & 178.29 & $4.66 \%$ \\
\hline
\end{tabular}

Source: Indonesia's SAM after simulation

Note: This is a result from the decrease in income caused by subsidy shock ( $1.24 \%$ decrease in income) plus the increase in income caused by infrastructure shock (5.89\% increase in income)

Scenario 2:

\begin{tabular}{ccccc}
\hline \multirow{2}{*}{ Code } & Initial Income & New Income & Changes & Growth \\
\cline { 2 - 5 } & & (Trillion Rupiahs) & & (\%) \\
\hline 18 & 176.76 & 187.44 & 10.68 & $6.04 \%$ \\
19 & 731.56 & 780.78 & 49.21 & $6.73 \%$ \\
20 & 494.23 & 519.08 & 24.85 & $5.03 \%$ \\
21 & 173.15 & 184.74 & 11.59 & $6.69 \%$ \\
22 & 468.45 & 511.20 & 42.74 & $9.12 \%$ \\
23 & 710.50 & 749.72 & 39.23 & $5.52 \%$ \\
24 & 243.91 & 260.37 & 16.46 & $6.75 \%$ \\
25 & 827.88 & 908.67 & 80.78 & $9.76 \%$ \\
\hline Total & 3826.44 & 4101.99 & 275.54 & $7.20 \%$ \\
\hline
\end{tabular}

Source: Indonesia's SAM after simulation

Note: This is a result from the decrease in income caused by subsidy shock (1.24\% decrease in income) plus the increase in income caused by infrastructure shock ( $8.44 \%$ increase in income) 
Avalaible online at http://journals.ums.ac.id, Permalink/DOI: 10.23917/jep.v20i1.7733

Jurnal Ekonomi Pembangunan: Kajian Masalah Ekonomi dan Pembangunan, 20 (1), 2019, 12-27

Appendix 8. Changes in Household Income from Scenarios 3 dan 4

Scenario 3:

\begin{tabular}{ccccc}
\hline \multirow{2}{*}{ Code } & Initial Income & New Income & Changes & Growth \\
\cline { 2 - 4 } & & (Trillion Rupiahs) & & $\mathbf{( \% )}$ \\
\hline 18 & 176.76 & 185.87 & 9.11 & $5.16 \%$ \\
19 & 731.56 & 772.44 & 40.88 & $5.59 \%$ \\
20 & 494.23 & 519.74 & 25.50 & $5.16 \%$ \\
21 & 173.15 & 183.08 & 9.92 & $5.73 \%$ \\
22 & 468.45 & 500.51 & 32.06 & $6.84 \%$ \\
23 & 710.50 & 747.40 & 36.91 & $5.19 \%$ \\
24 & 243.91 & 257.82 & 13.91 & $5.70 \%$ \\
25 & 827.88 & 886.50 & 58.61 & $7.08 \%$ \\
\hline Total & 3826.44 & 4053.36 & 226.92 & $5.93 \%$ \\
\hline
\end{tabular}

Source: Indonesia's SAM after simulation

Note: This is a result from the decrease in income caused by subsidy shock ( $1.24 \%$ decrease in income) plus the increase in income caused by infrastructure shock ( $7.17 \%$ increase in income)

Scenario 4:

\begin{tabular}{ccccc}
\hline \multirow{2}{*}{ Code } & Initial Income & New Income & Changes & Growth \\
\cline { 2 - 5 } & & (Trillion Rupiahs) & & $\mathbf{( \% )}$ \\
\hline 18 & 176.76 & 184.99 & 8.24 & $4.66 \%$ \\
19 & 731.56 & 767.77 & 36.21 & $4.95 \%$ \\
20 & 494.23 & 520.11 & 25.87 & $5.23 \%$ \\
21 & 173.15 & 182.14 & 8.99 & $5.19 \%$ \\
22 & 468.45 & 494.53 & 26.08 & $5.57 \%$ \\
23 & 710.50 & 746.10 & 35.61 & $5.01 \%$ \\
24 & 243.91 & 256.39 & 12.49 & $5.12 \%$ \\
25 & 827.88 & 874.08 & 46.20 & $5.58 \%$ \\
\hline Total & 3826.44 & 4026.13 & 199.69 & $5.22 \%$ \\
\hline
\end{tabular}

Source: Indonesia's SAM after simulation

Note: This is a result from the decrease in income caused by subsidy shock ( $1.24 \%$ decrease in income) plus the increase in income caused by infrastructure shock (6.45\% increase in income) 

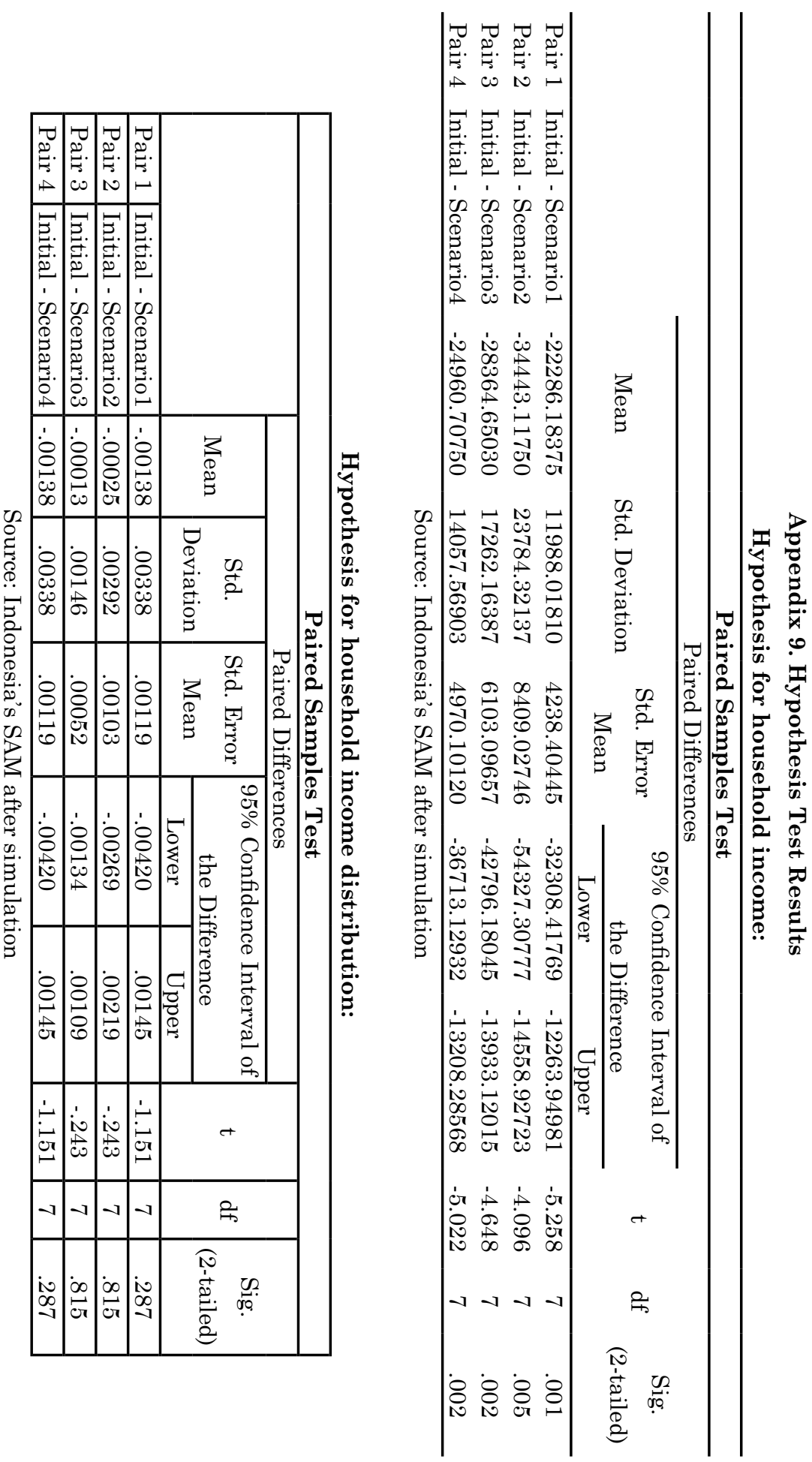